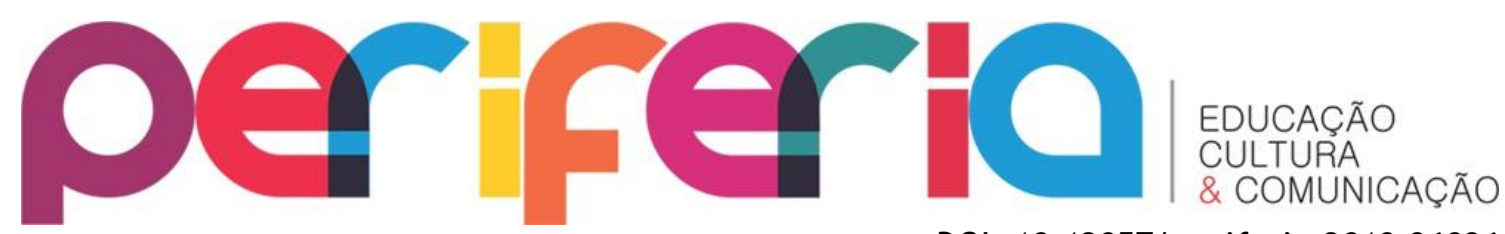

DOI: $10.12957 /$ periferia.2019.36936

\title{
MEMES EM SALA DE AULA: POSSIBILIDADES PARA A LEITURA DAS MÚLTIPLAS SEMIOSES
}

Helena Maria Ferreira ${ }^{1}$ Universidade Federal de Lavras Marco Antônio Villarta-Neder ${ }^{2}$ Universidade Federal de Lavras Geanne dos Santos Cabral Coe ${ }^{3}$ Universidade Federal de Lavras

\section{Resumo}

Com a disseminação das TDIC (Tecnologia digital de informação e comunicação), houve uma diversificação dos recursos semióticos para a organização dos textos que circulam na sociedade e, por consequência, a democratização de acesso a espaços de interação. Assim, considerando a configuração dos textos que exploram diversas linguagens simultaneamente, designou-se o seguinte problema: Que contribuições o gênero meme pode oferecer para a ampliação da proficiência de leitura e produção de textos por parte de alunos de Ensino Médio? Este artigo tem por objetivo socializar os resultados de uma pesquisa que analisou as potencialidades formativas advindas do trabalho com memes em sala de aula. A partir do trabalho empreendido, constatou-se que o gênero meme apresenta características substanciais para se pensar as multissemioses no ensino de língua portuguesa na escola e para a ressignificação de metodologias para a ampliação de habilidades relacionadas aos multiletramentos relacionados ao uso das diferentes linguagens. Dessa forma, é importante destacar que os memes se configuram como mecanismos que podem propiciar uma ressignificação do trabalho com textos, uma vez que as condições de produção podem ser revisitadas.

Palavras-chave: meme; multiletramentos; multissemiose

1 Departamento de Estudos da Linguagem. Programa de Pós-Graduação em Educação. helena.mferreira@uol.com.br

2 Departamento de Estudos da Linguagem. villarta-neder@del.ufla.br

${ }^{3}$ Mestranda em Educação pela Universidade Federal de Lavras. gegecabral@yahoo.com.br 


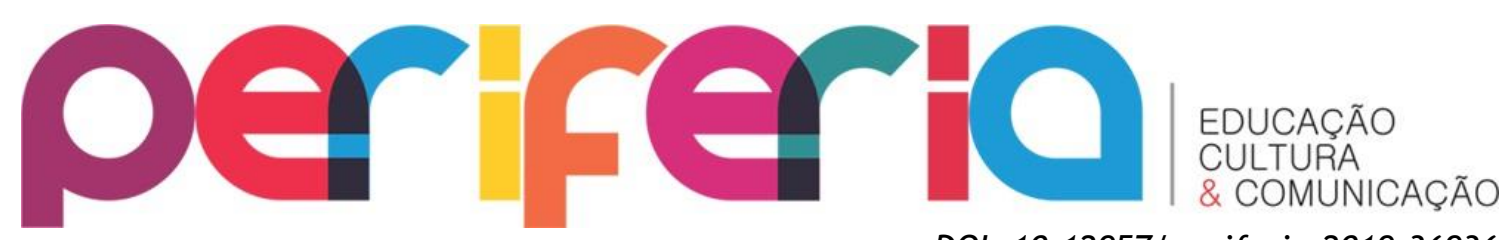

DOI: $10.12957 /$ periferia.2019.36936

\title{
MEMES IN A CLASSROOM: POSSIBILITIES FOR THE READING OF MULTIPLE SEMIES
}

\begin{abstract}
With the dissemination of the TDIC (Digital Information and Communication Technology), there was a diversification of the semiotic resources for the organization of the texts that circulate in society and, consequently, the democratization of access to spaces of interaction. Thus, considering the configuration of texts that explore several languages simultaneously, the following problem was identified: What contributions can the meme genre offer to broaden reading proficiency and text production by high school students? This article aims to socialize the results of a research that analyzed the formative potential of working with memes in the classroom. From the work undertaken, it was verified that the genre meme presents substantial characteristics to think about the multisemiosis in the teaching of Portuguese language in the school and for the re-signification of methodologies for the expansion of abilities related to the multiletramentos related to the use of the different languages. In this way, it is important to emphasize that memes are configured as mechanisms that can provide a re-signification of the work with texts, once the conditions of production can be revisited.
\end{abstract}

Keywords: meme; multiliteracies; multisemiosis 


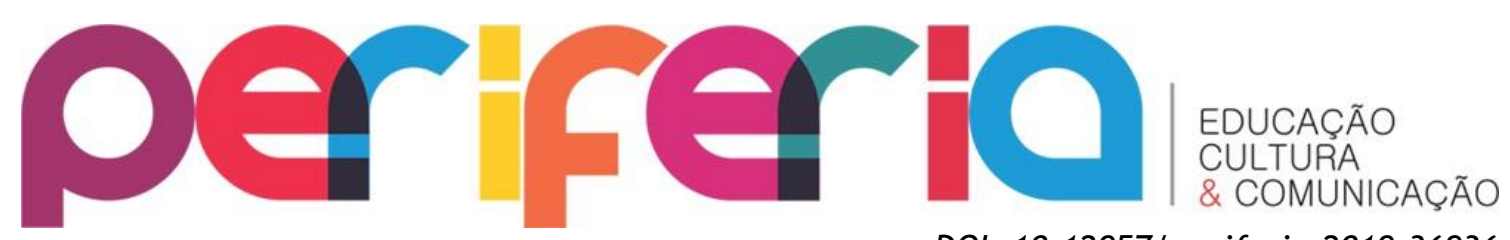

DOI: $10.12957 /$ periferia.2019.36936

\section{MEMES EN SALA DE CLASE: POSIBILIDADES PARA LA LECTURA DE LAS MÚLTIPLES SEMIOSIS}

\section{Resumen}

Con la diseminación de las TDIC (Tecnología digital de información y comunicación), hubo una diversificación de los recursos semioticos para la organización de los textos que circulan en la sociedad y, por consiguiente, la democratización de acceso a espacios de interacción. Así, considerando la configuración de los textos que explotan diversos lenguajes simultáneamente, se designó el siguiente problema: ¿Qué contribuciones el género meme puede ofrecer para la ampliación de la profesión de lectura y producción de textos por parte de alumnos de Enseñanza Media? Así, este artículo tiene por objetivo socializar los resultados de una investigación que analizó las potencialidades formativas derivadas del trabajo con memes en el aula. A partir de los trabajos realizados, se encontró que el género meme tiene características importantes que pensar en el multissemioses en la enseñanza del idioma portugués en la escuela y la redefinición de las metodologías para la expansión de las habilidades relacionadas con multiliteracías relacionadas con el uso de múltiples lenguajes. De esta forma, es importante destacar que los memes se configuran como mecanismos que pueden propiciar una resignificación del trabajo con textos, una vez que las condiciones de producción pueden ser revisadas.

Palabras clave: meme de la internet; multiliteracías; multissemiose 


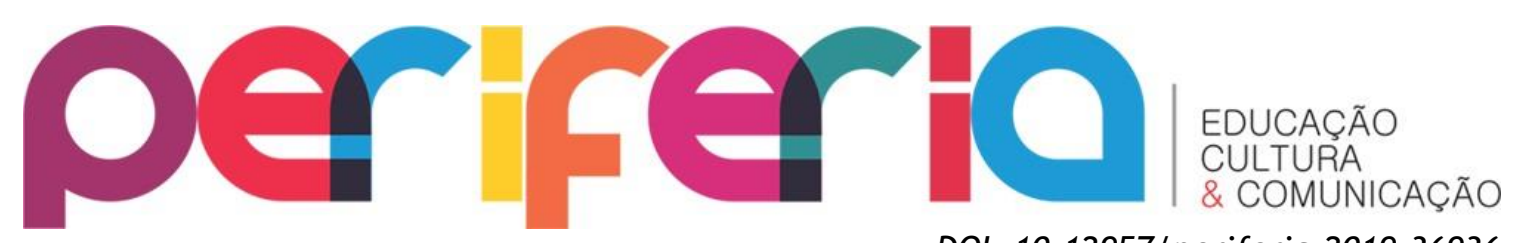

1 INTRODUÇÃO

DOI: $10.12957 /$ periferia.2019.36936

A disseminação das tecnologias de informação e comunicação trouxe impactos significativos para as interações sociais. Tais impactos estão relacionados ao redimensionamento das formas de recepção, de circulação e de produção dos diferentes gêneros discursivos, à ressignificação dos modos de comunicação utilizados para as interações sociais, às reconfigurações das questões ligadas ao conceito de autoria, à utilização de diferentes semioses, que são constitutivas dos textos que circulam em ambiente midiático, entre outros. Esse movimento traz demandas para os processos de ensinoaprendizagem, que precisam se adequar para a criação de situações didáticas que abarquem as peculiaridades dos textos que circulam socialmente e que se aproximem do contexto social, com vistas à formação de sujeitos críticos.

Os ambientes virtuais tendem a contribuir para o atendimento às exigências educacionais impostas pela sociedade da informação, que, notadamente, requer cidadãos críticos que possuam além da criatividade, criticidade para lidar com a quantidade de informações que circulam nas diversas situações sociocomunicativas.

Nesse âmbito, os gêneros discursivos se configuram como uma proposta de ensino-aprendizagem que viabiliza a exploração dos diferentes usos da linguagem. Entre tantos gêneros que os meios digitais têm apresentado intensivamente nos últimos anos, merece destaque o meme, um texto que implica um envolvimento mais ativo por parte do leitor, em função da natureza interativa desse gênero.

Para Silva, Francelino e Melo (2017, p. 178), o meme é considerado um gênero discursivo, pois

possui uma ancoragem em um espaço de criação e de recepção por sujeitos reais; está, pois, dialogicamente constituído das novas formas de interação do espaço virtual, sobretudo, daquelas presentes nas redes de comunicação existentes na internet, a exemplo do GIF. Ademais, possui os seus três componentes específicos apontados por Bakhtin, isto é, estruturalmente representado, demonstrando o conteúdo temático e o estilo de quem o produz. Em outros termos, o 


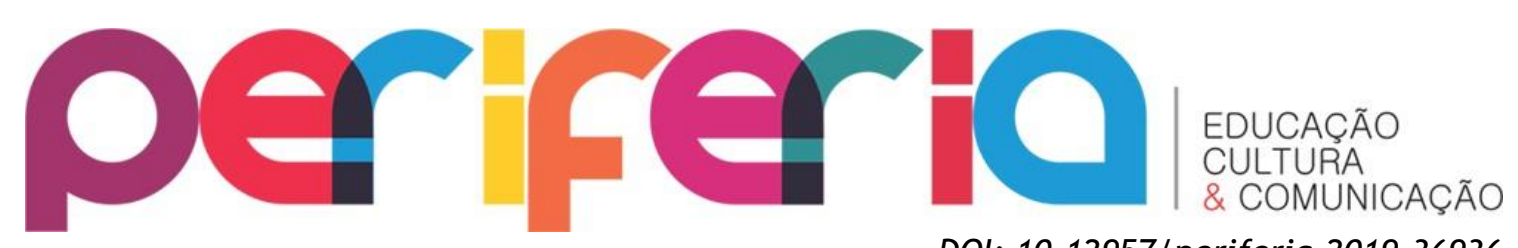

DOI: $10.12957 /$ periferia.2019.36936

gênero meme possui uma estrutura relativamente estável (fotos, gifs, frases, imagens, etc.), a qual denominamos estrutura composicional; trata e/ou refere-se sempre a um tema social que está na ordem do dia, o que compreende o conteúdo temático; por fim, carrega e manifesta, através de uma linguagem humorística, as intencionalidades de um dado enunciador - estilo.

Essas peculiaridades do meme tornam-no um texto flexível, divertido e rico no sentido de conjugação de diferentes semioses e diferentes finalidades.

Isto posto, destacamos que o presente artigo elege como proposta socializar uma experiência de produção do gênero meme em sala de aula, desenvolvida com alunos de ensino médio. Assim, o objetivo deste estudo é analisar as potencialidades do trabalho com o gênero meme para a ampliação de habilidades relacionadas aos usos da linguagem, em seus diferentes contextos e suportes, em suas múltiplas semioses.

Espera-se que este trabalho possa contribuir para uma reflexão acerca das propostas de ensino da leitura e da escrita no ensino médio, uma vez que as práticas pedagógicas nessa fase de escolarização têm se voltado para uma espécie de "treinamento" para a produção de textos exigidos para processos seletivos exigidos para ingresso no ensino superior, em detrimento de uma formação que também insira questões do cotidiano social para discussão.

Desse modo, este artigo, ao eleger o meme como objeto de estudo, pretende apresentar uma provocação acerca do trabalho com as múltiplas linguagens em sala de aula e evidenciar a relevância de uma discussão teóricometodológica pautada em uma perspectiva discursiva.

\section{MEME: ORIGEM E DESLOCAMENTOS}

Ao iniciarmos a explanação aqui proposta, consideramos válido enfatizar que o termo "meme" foi utilizado, originariamente, pelo zoólogo Richard Dawkins (1979), em sua obra O Gene Egoísta, para explicar a teoria de Charles Darwin sobre a molécula replicadora e, consequentemente, a evolução dos genes, que resultou na origem de todas as espécies. Dawkins (1979) usa o termo 


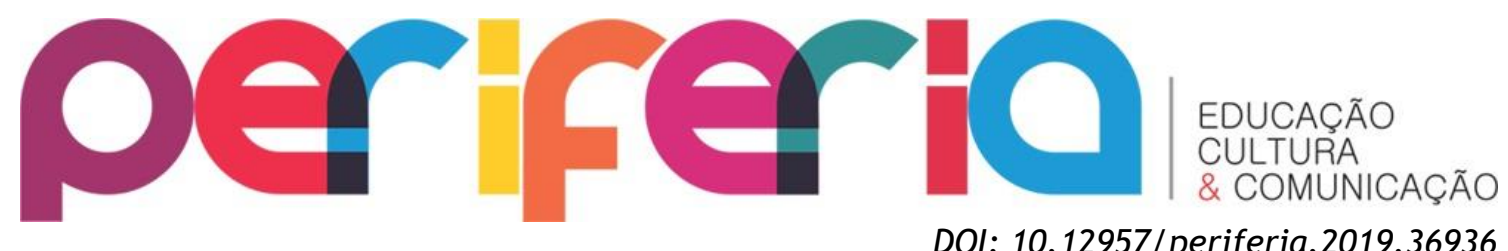

"meme", também como um replicador, porém no sentido de transmissão cultural, ou seja, expandir ideias, multiplicando sentidos. 0 autor reflete sobre a evolução biológica diferenciada de todos os seres vivos (gene) e a evolução cultural experenciada pelos humanos e algumas espécies de animais (meme).

Comentando a posição de Dawkins (1979), Martino e Grohmann (2017) explicam que o termo meme pode ser definido como uma unidade de cultura transmitida de uma pessoa para outra. "A ideia de 'transmissão' sugere sua base biológica: na medida em que, a transmissão cultural é análoga à transmissão genética, o meme é uma unidade de transmissão cultural, ou unidade de imitação" (p. 95).

Prosseguindo com o percurso histórico do surgimento dos memes, podemos considerar que esse gênero foi conceituado como meme muito antes da era digital, mas as características interativas das redes sociais propiciaram uma disseminação cada vez mais popular. É certo que o acesso aos ambientes virtuais possibilitou que esses replicadores de interação se ressignificassem, caíssem no gosto dos internautas e ampliassem os espaços de humor, tão comuns em nossa cultura.

De acordo com Horta (2015), o primeiro registro da palavra "meme" na internet é de 1998. Segundo a autora, Joshua Schachter produziu o Meme pool, um site que agregava links virais e outros assuntos. No início dos anos 2000, Jonah Peretti, o criador de Contagious Media (um site por meio do qual se realizavam experimentos virais), realizou um "festival de virais" que contribuiu para a disseminação e para a criação de artefatos culturais na web.

A partir disso, em conformidade com Silva (2016), os memes passaram a ser identificados como uma produção composta "por imagens, por figuras, fotografias, frases, palavras-chave ou qualquer outro elemento que apresente um conteúdo irônico ou humorístico que se propague ou se replique na rede" (p.342).

Segundo afirmam Martino e Grohmann (2017),

Os memes encontram sua materialidade na forma de imagens, vídeos, frases, enunciados, discursos e mesmo práticas sociais presentes nos mais inesperados espaços, mas, em especial, 


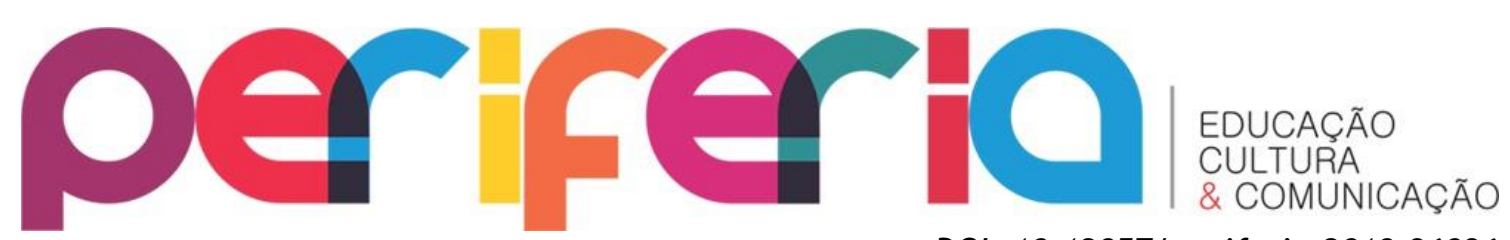

DOI: $10.12957 /$ periferia.2019.36936

podem ser encontradas no ambiente das mídias digitais, nos quais a proliferação de memes parece ser particularmente alta (p. 96).

Essa proliferação foi ampliada com o advento das mídias digitais, que partem de acontecimentos, notadamente, com propósitos de entretenimento, crítica social, exposição de pontos de vista etc. Como afirmam Martino e Grohmann (2017, p. 97), “em sua utilização corrente, memes são imagens, dos mais variados tipos, às quais são geralmente acrescentadas palavras que auxiliam a compor uma determinada mensagem", com a função de replicar uma frase, uma ideia, um vídeo e ampliar seus sentidos.

Nessa perspectiva, os autores supracitados explicam que

memes são um dos principais elementos da cultura digital. Definidos como uma ideia que se espalha entre seres humanos, em um sentido próximo dos genes, encontraram na velocidade dos ambientes digitais um espaço particularmente adequado para sua multiplicação, uma vez que a rapidez de transmissão é uma de suas características fundamentais (2017, p. 94).

As novas tecnologias digitais de informação e comunicação (TDIC) possibilitam que as mensagens sejam transmitidas com muita rapidez, até mesmo em tempo real. Essa característica confirma a posição de Takaki (2012, p. 55) que afirma que "palavras e imagens digitais tomam a forma de códigos semióticos e são: fluidos, adaptáveis, abertos sem fronteiras, processáveis, duplicáveis, podem ser recolocados para infinitas redes de conexão com rapidez". Assim se caracterizam os memes.

Nessa direção, Horta (2015) traduz o comentário de Dawkins sobre o meme na internet e destaca que a própria ideia de meme foi ressignificada, o que desencadeou novas configurações, constituindo-se como um sequestro da ideia original. No entanto, vale destacar que essas novas configurações não se efetivam ao acaso. As modificações nesse gênero discursivo são realizadas conscientemente pelos produtores, que utilizam da criatividade para cumprir o propósito comunicativo e para estabelecer interações com diferentes usuários.

Nessa versão sequestrada, há modificações substanciais, pois é possível não se restringir à escrita, utilizando as multissemioses, como imagens, cores, 


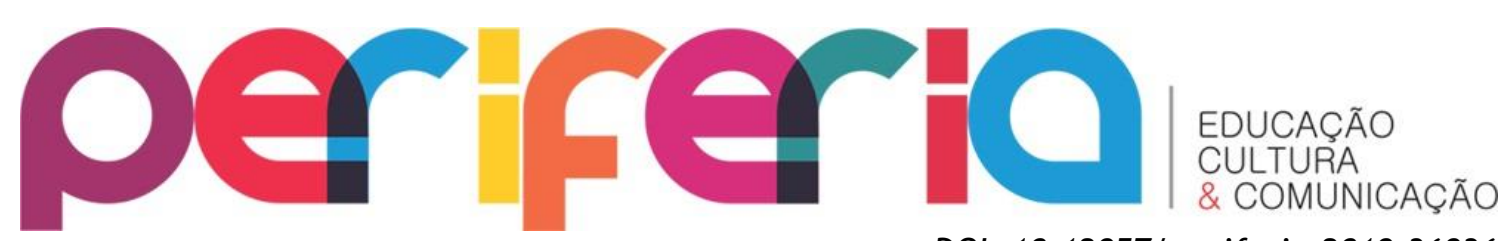

DOI: $10.12957 /$ periferia.2019.36936 sons, entre outros, que são acessíveis em função da popularização dos recursos tecnológicos. Nesse contexto, a noção de imitação como transferência cultural assume uma dimensão notadamente complexa quando se trata de meme da internet.

Em dimensão discursiva da linguagem e a partir das configurações assumidas pelo gênero meme na contemporaneidade, podemos considerar que o conceito de imitação dos memes - preconizado por Dawkins a partir dos genes - pode ser ampliado a partir da noção de intersubjetividade, que diz respeito a “conhecimentos compartilhados entre os enunciadores e aponta para um objeto de discurso aparentemente já conhecido pelos enunciadores, ainda que não esteja presente no contexto". (CASTRO, 2017, p. 54). Nessa dimensão, podemos recorrer à noção de dialogismo, pois, na acepção proposta por Bakhtin ${ }^{4}$,

[...] o que mais se fala no dia a dia é sobre o que dizem os outros: transmitem-se, recordam-se, ponderam-se, discutemse as palavras alheias, opiniões, afirmações, notícias, indignase com elas, concorda-se com elas, contestam-nas, referem-se a elas, etc. (BAKHTIN, 2015, p. 131)

Nesse percurso, os enunciados estão repletos de palavras dos outros, ocultas, semi-ocultas ou explícitas e com graus diferentes de alteridade, ou seja, as "palavras dos outros trazem consigo a sua expressão, o seu tom valorativo que assimilamos, reelaboramos, e reacentuamos." (BAKHTIN, 2011, p. 295) Ao produzirmos discursos, não somos a fonte deles, porém intermediários que dialogam e polemizam com os outros discursos existentes em nossa sociedade, em nossa cultura. Nessa relação dialógica, o discurso é um jogo, é movimento, tentativa de transformação e mesmo subversão dos sentidos.

Esclarecendo o exposto, podemos considerar, em conformidade com Sousa (2015), que os memes podem ser compreendidos como enunciados, pois

\footnotetext{
${ }^{4}$ De acordo com Sousa (2015, p. 2), pensar o "meme" como um enunciado concreto, tal como esta noção é desenvolvida por Bakhtin (2011), implica em concebê-lo como um gênero típico da comunicação na mídia digital, cuja base de produção ocorre em relações dialógicas, pois sempre que um acontecimento ganha notoriedade e começa a ser propagado na mídia, surgem réplicas diversas de enunciados que fazem referência a ele.
} 


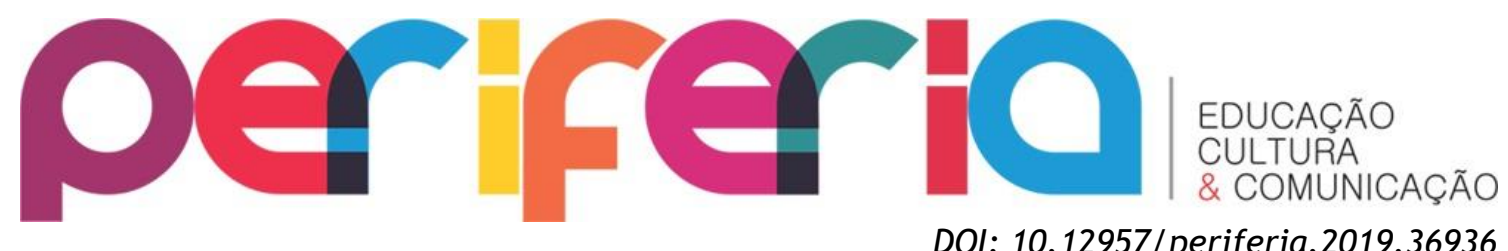

DOI: $10.12957 /$ periferia. 2019.36936 possuem um vínculo com a realidade social na qual são construídos. Sem essa articulação, fica complicado compreendê-los, já que não são apenas um emaranhado verbal a ser decifrado. Eles possuem um autor e também um auditório, já que na web, os interlocutores são diversos, o que torna o enunciado de fato, um espaço de tensões e polêmicas.

Os memes são textos que explicitam a natureza notadamente interativa da linguagem, uma vez que os sentidos são produzidos de modo bastante evidente a partir das relações entre os enunciados (porque são relações entre os sujeitos que participam da enunciação, se constituem por ela e a constituem), ao contrário de outros textos em que esse acontecimento ocorre de forma menos explícita.

Além disso, esse gênero favorece uma situação interlocutiva em que os sujeitos situam seu discurso em relação aos discursos do outro, sendo esse outro não somente aquele a quem se dirige o discurso (nível intradiscursivo), mas também outros discursos historicamente constituídos e que ganham voz no discurso do sujeito (nível interdiscursivo ${ }^{5}$ ). Desse modo, embora seja necessário considerar a natureza mêmica desse gênero, não podemos ignorar as questões ligadas aos modos de circulação e aos processos de retextualização (transformação dos textos) advindos da interação em que os memes se fazem presentes.

\section{MEMES EM SALA DE AULA}

0 meme pode ser caracterizado como um gênero que apresenta circulação aberta, uma vez que é veiculado em redes sociais e em outras mídias, tais como televisão, revistas, jornais. Entretanto, devido aos seus diversos recursos semióticos, é necessário atentar-se para os diferentes elementos indiciadores de sentido para que a compreensão não seja comprometida. Para Escalante (2016, p.15), “o meme aparenta ser um tipo de

\footnotetext{
${ }^{5}$ Adotamos aqui a noção de que " $L$ ' interdiscours d' une formation discursive peut ainsi être saisi comme ce que régle le déplacement de ses frontières. (Courtine \& Marandin, 1981, 25)". ( 0 interdiscurso pode assim ser tomado como o que regula o deslocamento das fronteiras de uma formação discursiva." - Tradução de Guilherme F. Borges e Carmem L. da Silva).
}

Periferia, v. 11, n. 1, p. 114-139, jan./abr. 2019 


\section{periferio}

DOI: $10.12957 /$ periferia.2019.36936 mídia de linguagem simples. Porém, alguns requerem repertório de conhecimentos em campos diversificados como línguas estrangeiras, História, Matemática, atualidades e/ou outros produtos de entretenimento, para serem decodificados e compreendidos”.

Assim, na produção de um meme, o(s) produtores pode $(\mathrm{m})$ explorar recursos semióticos (imagens estáticas ou em movimento, cores, palavras, tipografias, discursos etc.) para a constituição do texto, mas para entender a(s) proposta(s) de sentido(s) apresentadas pelo(s) autor(es) é necessário que o(s) leitor(es) recupere $(\mathrm{m})$ as pistas fornecidas para a interpretação, o que demanda a mobilização de conhecimentos prévios, a realização de inferências, a percepção das relações intertextuais, além de habilidades relacionadas aos multiletramentos, que abarcam dimensões culturais inerentes aos textos e dimensões semióticas relativas aos efeitos de sentido decorrentes das escolhas dos recursos utilizados na produção.

Além das peculiaridades destacadas até aqui, Shifman (2014) também ressalta que os memes possuem três particularidades, a saber: a) a transmissão de informações culturais de pessoa para pessoa e se transformam em um fenômeno social ao ser compartilhado; b) a reprodução por diversos ambientes de mimetismo (imitação) e remixagem (reedição de conteúdo com um novo formato) e c) a diversificação quanto à adaptação ao meio sociocultural em que se propagam, uma vez que apresentam relação bastante íntima com o contexto de produção ou de circulação.

Para além do exposto, Shifman (2014) e Escalante (2016) asseveram que os memes assumem, notadamente, uma função no processo de difusão da informação e da construção do conhecimento. Escalante (2016) ainda ressalta que o meme carrega "uma gama de referências (intertextualidades) a outros produtos de entretenimento, situações culturais e a fenômenos sociais e políticos” (p. 19).

Complementando o exposto, Horta (2015) acrescenta que os memes, apresentados em vídeos, frases, hashtags, fotolegendas, tirinhas, montagens, entre outras manifestações, têm por característica o fato de terem sofrido uma intervenção direta de quem os reproduz, o que os diferenciam dos virais que 


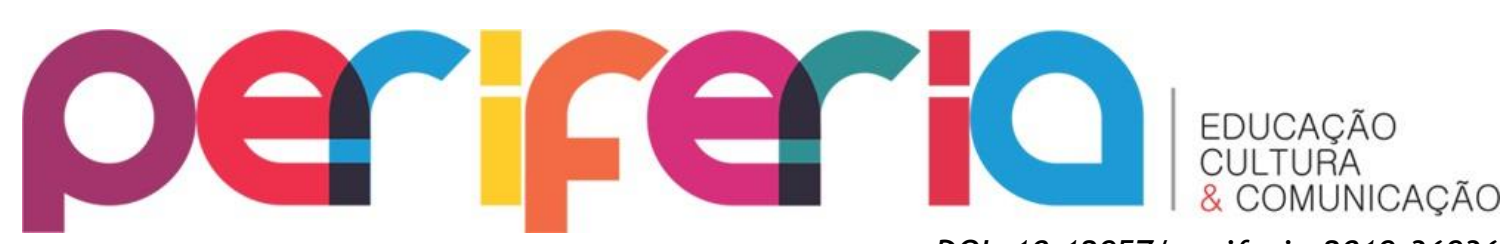

DOI: $10.12957 /$ periferia.2019.36936 são vídeos que foram largamente compartilhados, sem necessariamente ter passado por um processo de recriação.

Diante das considerações feitas, podemos considerar que os memes não são unidirecionais, controlados ou autorais, assim como outras criações feitas nos espaços virtuais (textos, vídeos, músicas). Esses textos que exploram as TDIC, como afirma Rojo (2016), são “colaborativos e interativos dilui (e no limite fratura e transgride) a própria ideia de propriedade das ideias: posso passar a me apropriar do que é visto como um 'fratrimônio' da humanidade e não mais como um 'patrimônio'” (p.25).

Pela sua natureza interativa, os memes podem ser considerados como potencializadores de habilidades relacionadas aos multiletramentos, uma vez que permitem a exploração de diferentes estratégias de leitura e de produção de textos em uma perspectiva discursiva.

Com a disseminação das TDIC na sociedade, houve um avanço considerável na multiplicidade de textos que integram às interações sociais, o que, de certa forma, traz uma demanda para um redimensionamento das práticas educativas.

Nessa direção, Santos e Santos (2013, p. 49), postulam que

é necessária e urgente a aproximação entre os campos da Educação e da Comunicação, assim como a compreensão de que ver, ouvir, interagir, criar, compartilhar, é uma urgência e um dos grandes desafios para o professor da contemporaneidade. Mudanças profundas foram provocadas pela extensão e desenvolvimento das redes interpessoais de comunicação. Cada um pode apropriar-se dos diversos formatos digitais e tornar-se criador, compositor, colaborador. A partir disso, é possível criar e potencializar processos criativos que tenham o digital como suporte, como é o caso das mídias digitais e das redes sociais.

A citação acima evidencia a relevância de um processo educativo articulado à vida social, em que os alunos sejam capazes de refletir sobre os usos da linguagem em suas interações interpessoais. Reiterando o exposto, Ribeiro (2016) destaca a importância de pensar como têm sido tratados os textos multimodais na escola, "que lugares eles ocupam na vida dos estudantes dentro e fora da sala de aula”. (p. 31). Entre esses textos, merecem destaque os memes, que apresentam peculiaridades que podem contribuir para a 


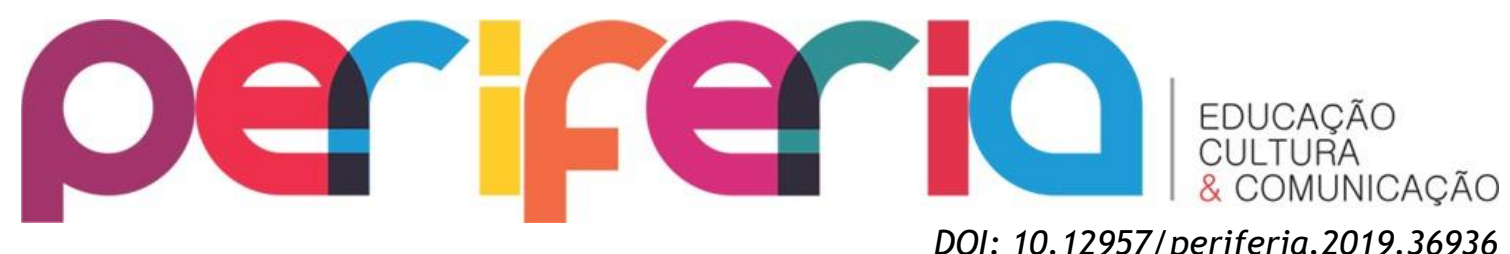

ampliação de diferentes habilidades formativas voltadas para as práticas de leitura e de escrita de textos na escola.

Considerando essas peculiaridades, discorreremos sobre cinco potencialidades que podem ser propiciadas pelo trabalho com memes em sala de aula. Inicialmente, destacamos a possibilidade de uma reflexão sobre as condições de produção dos discursos. Essas condições estão relacionadas às características básicas do contexto interlocutivo acionadas pelos sujeitos, de forma consciente ou inconsciente, no decorrer do processo de produção dos diferentes gêneros discursivos.

Nesse sentido, o meme se qualifica como um texto bastante apropriado para uma análise nas práticas educativas, pois apresenta peculiaridades que permitem uma reflexão acerca dos processos de produção, de circulação e de recepção dos textos. Esse gênero pode apresentar características diversas, uma vez que podem ser replicados, transmutados ou mimetizados, conforme apresentado na seção anterior. Isso coloca em questão os modos de funcionamento dos textos em circulação.

Desse modo, podemos apontar potencial dos memes para um deslocamento das práticas de ensino da leitura e da produção de textos pautadas em uma perspectiva que dá primazia apenas em sua materialidade linguística, como um produto pronto e acabado para uma abordagem que contemple as dimensões discursivas da linguagem, inserindo o contexto de produção e de recepção e as finalidades do texto como objeto de discussão.

Em segundo lugar, destacamos que os memes se configuram como um exemplar para uma reflexão sobre a constituição dos discursos, explicitando a questão da natureza responsiva da linguagem. Para Volóchinov (2017), o enunciado é eminentemente dialógico, isto é, estabelece relações de sentido entre si. Nessa acepção, ele é uma réplica, uma resposta responsiva ativa, uma vez que sempre responde a algo e suscita uma nova resposta. Dessa forma, dois enunciados, separados por espaço e por tempo distintos, podem estabelecer relações de sentidos. Nessa perspectiva, o diálogo não se limita à instância imediata de enunciação, mas se estende social e historicamente, "porque o 


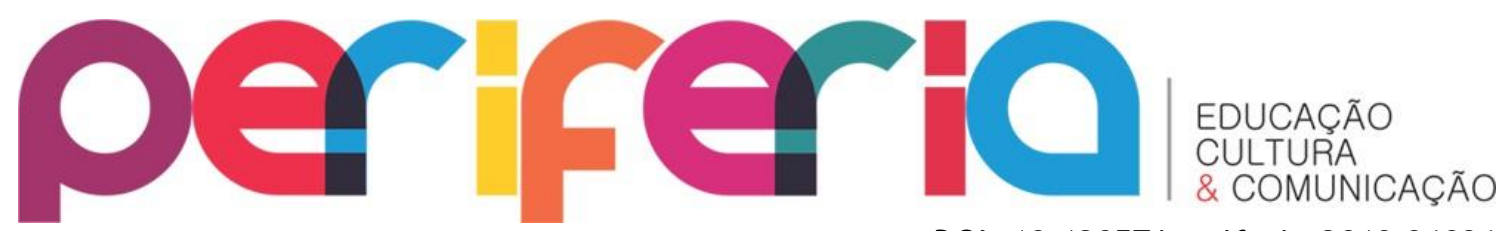

DOI: $10.12957 /$ periferia.2019.36936

diálogo social soa no próprio discurso, em todos os seus elementos, sejam 'conteudísticos', sejam 'formais'.” (BAKHTIN, 2015, p. 77)

Os memes comportam três características básicas que evidenciam 0 diálogo social: a) caráter "normativo", de formação de regras de funcionamento que os caracterizam enquanto tais; b) aspecto social, de partilha, o que faz deles forma de comunicar, bem como a existência de "falantes" dessa linguagem; e c) natureza interativa de produzir sentido (ou novos sentidos) às coisas do mundo, de ressignificar informações, imagens, vídeo, textos.

Para Geraldi (2015, p. 103),

Ler não é apenas reconhecer o signo com suas significações do passado. Ler é construir uma compreensão no presente com significações, que, entranhadas nas palavras, são dissolvidas pelo seu novo contexto - que incluem também as contra palavras do leitor - para permitir a emergência de um sentido concreto, específico e único, produto da leitura que se está realizando. Neste sentido, a leitura é também co-produção do texto, uma atividade orientanda por este, mas que the ultrapassa.

Nesse contexto, podemos considerar que o trabalho com meme favorece uma ressignificação das práticas de leitura e de escrita em sala de aula, pois pode contribuir para a minimização de práticas que incentivam "a formação do leitor que repete leituras do professor", ou seja, de propostas que se restringem à exigência de resultados imediatos, como ler para responder às perguntas, ler para produzir um texto em um mesmo formato, ler para realizar uma pesquisa, "todas atividades que revelam a expectativa de um resultado desenhado como imediato após a leitura" (GERALDI, 2015, p. 111).

Ler e produzir meme demandam uma relação com o contexto sociocomunicativo, exigem um posicionamento por parte dos sujeitos, mobilizam para a interação, incita a criatividade. Esse processo posto em funcionamento “exige articulações entre situação, relação entre interlocutores, temática, estilo do gênero e estilo próprio, o querer dizer do locutor, suas vinculações e suas rejeições aos sistemas entrecruzados de 


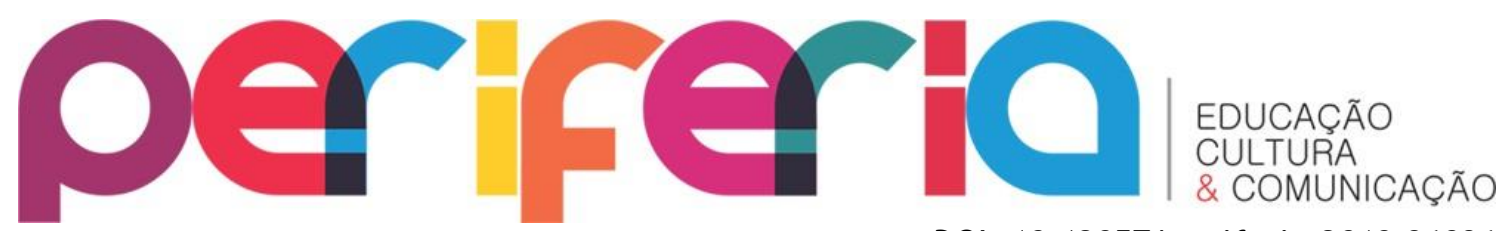

DOI: $10.12957 /$ periferia.2019.36936 referências com as quais compreendemos o mundo, as pessoas e suas relações." (GERALDI, 2015, p. 141)

Assim, introduzir a leitura/produção de memes em sala de aula significa abrir a possibilidade de imprevistos e de instabilidades e, ao mesmo tempo, de reflexão sobre as semioses ${ }^{6}$ constitutivas dos textos e que contribuem para o indiciamento de sentidos. Vale destacar também a possibilidade de uma discussão acerca das crenças, valores, atitudes, muitas vezes, não observados nos processos de compartilhamento, o que pode desvelar ideias preconceituosas e/ou caricaturais.

Em terceiro lugar, destacamos outra contribuição dos memes, que está relacionada à reflexão sobre a intertextualidade constitutiva dos textos. Os memes apresentam características eminentemente intertextuais devido ao fato de apresentar uma articulação com outras produções textuais. Essa afirmação pode ser confirmada a partir de Meili (2014), que investigou a natureza intertextual dos memes.

Os memes são compreendidos com base na categoria analítica do intertexto, pois, na prática, perpassam inúmeros textos (multimídias), constituindo paródias e outras formas de referência. Eles são "ativadores culturais" no ambiente da internet (JENKINS, 2006), funcionando como catalisadores e desencadeando processos de construção compartilhada de significados. [...] O meme funciona como uma voz (que, em si, também é heterogênea) que perpassa uma infinidade de outras vozes (em forma de intertexto) no espaço da rede semântica da internet. A voz de um enunciado, quando ele se torna um meme não é mais subjetiva, mas histórica e compartilhada, as apropriações do meme são, por sua vez, subjetivas e resultantes de um processo de identificação (p. 355/362).

Nesse sentido, podemos perceber que intertextualidade presente no meme se configura tanto no seu processo de produção (aproveitamento de uma semiose, tal como uma imagem ou frase típica), quanto no seu processo de

\footnotetext{
${ }^{6}$ Analisar as semioses significa descrever, interpretar e explicar os processos de produção, reprodução, circulação e recepção de textos e como sujeitos os interpretam em contextos de situações e/ou práticas específicas, abarcando a combinação de palavras, de imagens, de cores, de sons, de movimentos etc.
} 


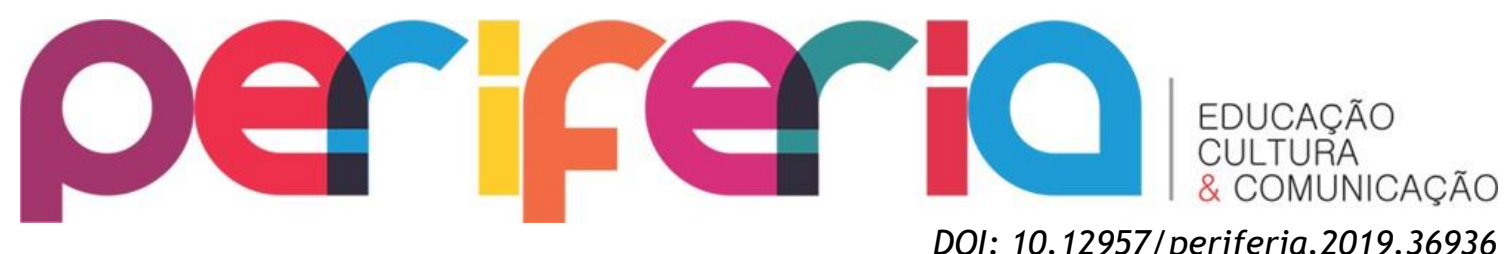

DOI: $10.12957 /$ periferia.2019.36936 recepção (participação na formação de novos enunciados e discursos). Assim, passa a ter "um valor informacional comum e funciona como um contextualizador (informação velha) para ancorar novas informações, o seu valor é agregado à informação nova, principalmente pela sua visibilidade, chamando a atenção para ela" (MEILI, 2014, p.366).

Considerar a natureza intertextual dos memes poderá propiciar a compreensão das formas de organização da textualidade semiótica dos textos que circulam em ambiente interativo, uma vez que a conexão intertextual se constitui como um importante recurso para a produção da coerência e da dinâmica do conjunto informacional.

Em quarto lugar, destacamos a possibilidade de uma reflexão sobre as diferentes semioses constitutivas dos textos que circulam em ambiente digital. Os memes, normalmente, por sua curta extensão, propiciam uma análise articulada dos diferentes recursos utilizados para o processo de construção de sentidos.

Para Horta (2015, p. 21), “o meme pode ser pensado, assim, como ação do signo, isto é, uma mediação estabelecida entre algo a que ele se refere, ou se aplica, e os efeitos que são produzidos na mente de quem se põe em relação a esse objeto - informações “lidas e escritas” em sua linguagem”. Nesse sentido, podemos nos reportar ao conceito de semiosfera ${ }^{7}$, que caracteriza os memes como um gênero que possui especificidades peculiares, que abarca questões de linguagem e dos sistemas culturais.

Nessa direção, podemos admitir que os gêneros discursivos se organizam de um modo particular (com suas possibilidades de variação), o que permite o reconhecimento de um texto como pertencente a um determinado gênero. Essa configuração é constituída por questões de natureza linguística/semiótica e por questões culturais. A regularidade a partir desses diversos usos é o que vai

\footnotetext{
${ }^{7}$ A semiosfera pode ser compreendida como uma esfera sígnica que não se restringe a soma de códigos, linguagens e textos que por ela transitam (Lotman, 1990, 123). Ela pode ser vista como um ambiente no qual diversas formações semióticas se encontram imersas em diálogo constante, um espaço-tempo, cuja existência antecede tais formações e viabiliza o seu funcionamento, enquanto torna possível seu próprio ciclo vital. (RAMOS; MELLO; CAVALCANTTI, 2007, p.34)
} 


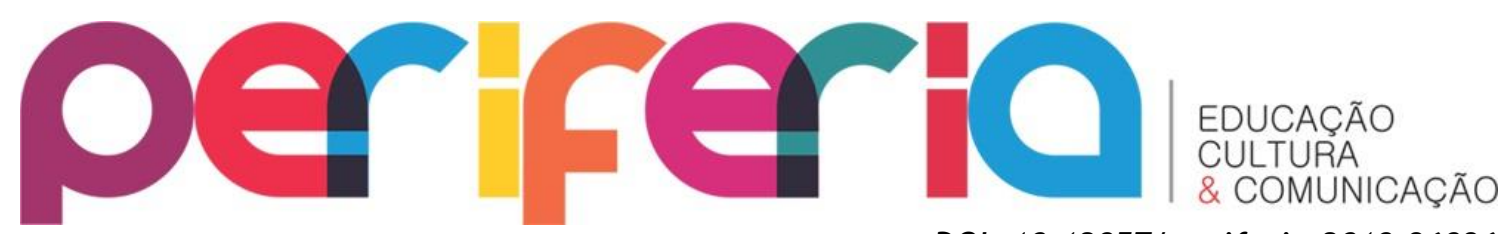

DOI: $10.12957 /$ periferia.2019.36936

configurar certa "gramática", delineando, de maneira não rígida, que formações textuais podem ser consideradas como pertencentes àquele gênero ou não.

Discorrendo sobre a gramática dos memes, Horta (2015, p. 21) considera que os memes, como um gênero discursivo, comportam três pontos:

primeiro por seu caráter "normativo", de formação de regras de funcionamento que os caracterizam enquanto tais; também por seu aspecto social, de partilha, o que faz dele forma de comunicar: se pensamos o meme como linguagem, podemos imaginar a existência de "falantes" dessa linguagem; e em terceiro lugar o caráter do meme que diz respeito à maneira de dar sentido (ou novos sentidos) às coisas do mundo, de ressignificar informações, imagens, vídeo, textos. De modo algum esses três aspectos estão separados, na realidade, um implica o outro.

Nessa dimensão, para a autora supracitada, entender um meme "depende do conhecimento de suas regras e dinâmicas para produzir significados" (HORTA, 2015, p. 21), ou seja, implica compreender o seu funcionamento e seus usos nas práticas de linguagem. Essa compreensão exige um conhecimento de certas regras e do contexto de emissão e recepção, bem como a análise da situação comunicativa que configura os modos como as semioses articuladas nesse tipo de texto. Assim, os recursos semióticos, sejam eles constantes de memes estáticos ou em movimentos, são considerados integrantes do processo de indiciamento de sentidos e não se configuram como elementos aleatórios, pois advêm de escolhas feitas pelo produtor e orientam interpretações.

De acordo com Ferreira e Villarta-Neder (2017, p. 70), “estudar a linguagem em seus aspectos semióticos é considerar as escolhas e as combinações sígnicas e suas formas de organização para direcionar sentidos e para evocar interpretações". Nesse sentido, as expressões faciais, postura corporal, atitudes, cores, movimentos, sons, palavras, imagens, diagramação, planos, enquadramentos, saliência, design etc. sinalizam possibilidades interpretativas. Nessa concepção, os textos são considerados como um sistema de signos verbais e não verbais, que se organizam nas dimensões linguístico- 


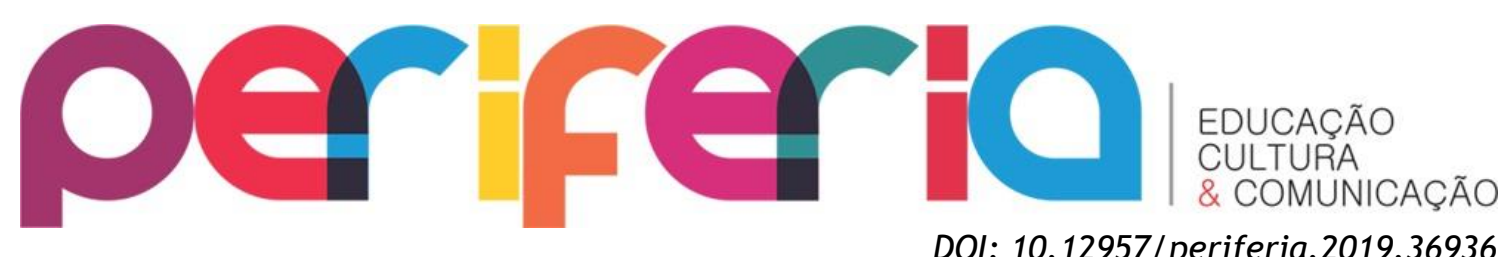

DOI: $10.12957 /$ periferia.2019.36936 semióticas e discursivas. Essa configuração demanda do leitor novas habilidades para a depreensão dos elementos e das combinações sígnicas que participam do processo de produção dos sentidos.

Considerando o exposto, podemos atestar que os memes oferecem possibilidades para uma análise das multissemioses, em uma perspectiva enunciativa, já que os recursos semióticos e os interlocutores (enunciador e enunciatário) se configuram também como signos da textualidade, uma vez que integram o circuito de produção, circulação e recepção.

Por fim, em quinto lugar, podemos reiterar a importância dos memes para uma reflexão acerca do compromisso ético nas redes sociais. Nesse sentido, os memes, apesar de sua configuração notadamente de cunho humorístico, também podem cumprir outras finalidades comunicativas nas diversas situações de circulação. Assim, Guerreiro e Soares (2016, p. 186) atestam que esse tipo de texto "presente nas redes sociais, é destinado, comumente, para efeito de humor, porém, percebe-se também uma crítica social, política e cultural".

É possível propor uma análise que comporte a dimensão da escolha lexical, da seleção de imagens, da organização do texto, do perfil do leitor e a adequação do texto à situação sociocomunicativa. Os autores consideram que a análise de memes representa uma possibilidade para verificar como ocorre a construção do sentido, "levando em consideração os personagens presentes, a interação com o observador e a composição das imagens, bem como o momento da produção, a inferência do leitor, a cultura e o contexto social.” (GUERREIRO; SOARES, 2016, p. 189)

A formação do leitor, na perspectiva dos multiletramentos, implica a ampliação das possibilidades de participação em atividades sociais diversificadas, entre elas, o compartilhamento de informações em redes sociais, bem como a capacidade de análise dessas atividades em uma perspectiva crítica, ou seja, de avaliar a existência de disseminação de preconceitos, inverdades ou de questões que se distanciem de um comportamento ético. 


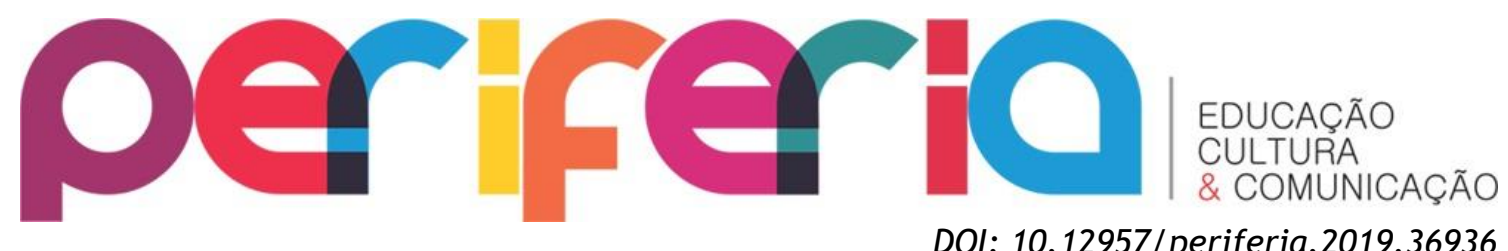

DOI: 10.12957/periferia.2019.36936

Nesse contexto, considerando a ressignificação das interações em função do uso das redes sociais, Rojo (2016, p. 112) destaca a relevância implementar, na escola e fora dela, os letramentos críticos, que podem favorecer a discussão acerca da relação "com os textos e com os discursos naturalizados neutralizados, de maneira a perceber seus valores, suas intenções, suas estratégias, seus efeitos de sentido." Nessa direção, o estudo dos textos não fica restrito à dimensão gramatical/textual, mas se amplia para a "abrangência dos discursos, das ideologias e das significações, como tanto a escola quanto as teorias se habituaram a fazer."

Os memes, em função de sua natureza interativa, possibilitam a mobilização de conhecimentos prévios e a compreensão de que a leitura é uma prática social, pois não se lê apenas para responder perguntas, como, muitas vezes, acontece na escola. Ler memes pode viabilizar a implementação de práticas pautadas no caráter dialógico da linguagem e, consequentemente, problematizar questões ligadas à dimensão social e histórica, transformando a leitura em uma atividade constitutiva de sujeitos capazes de estabelecer relações com o mundo e nele atuar como cidadãos.

\section{ANÁLISE DE MEMES PRODUZIDOS POR ALUNOS DE ENSINO MÉDIO}

Com vistas a analisar o potencial para a formação de leitores e produtores de textos, realizamos um projeto de intervenção, envolvendo o gênero meme. 0 projeto foi desenvolvido em uma escola rural, situada no município de Lavras (MG), envolvendo cerca de 90 alunos de ensino médio e faz parte de uma pesquisa mais ampla sobre o trabalho com textos multissemióticos em sala de aula, realizada no âmbito do Grupo de Pesquisa Textualiza (UFLA/CNPq).

Inicialmente, as atividades foram desenvolvidas a partir de uma pesquisa sobre memes que foi proposta aos alunos. Posteriormente, foi realizada uma discussão com os alunos, a partir de um material explicativo e de algumas imagens, abarcando o que são e como se caracterizam os memes de 


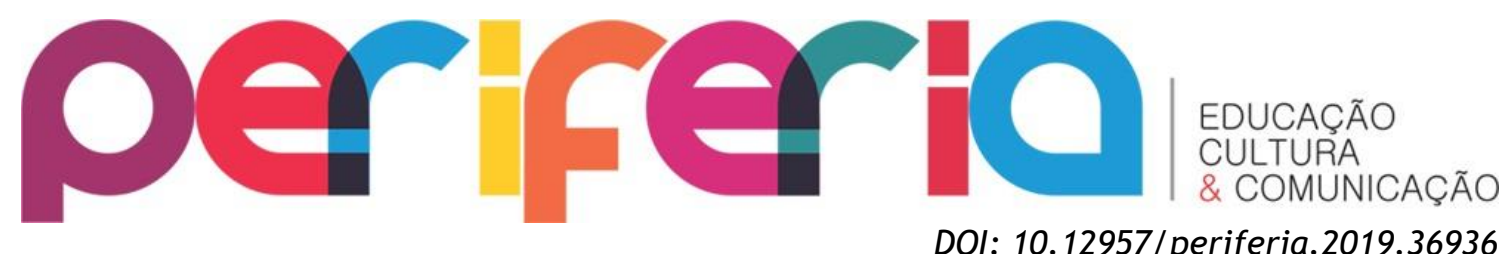

internet. Já a proposta de produção foi pautada em um roteiro que foi elaborado coletivamente após as discussões sobre o gênero meme.

A coleta de dados foi feita a partir das produções dos alunos e de diários de aula produzidos pela professora (ZABALZA, 2004). A seleção do corpus se deu a partir do critério de melhor representatividade para ilustrar a questão discutida neste trabalho.

A partir da produção, podemos sistematizar as potencialidades dos memes, o que abarca uma discussão sobre:

1) as condições de produção dos discursos

2) a constituição dos discursos

3) a intertextualidade constitutiva dos textos

4) as diferentes semioses constitutivas dos textos digitais

5) o compromisso ético nas redes sociais.

Em função de os memes terem sido produzidos a partir de uma proposta escolar, os interlocutores visados foram os próprios colegas e amigos, o que permitiu uma análise sobre os processos de produção, circulação e recepção dos textos. É relevante destacar que as produções não foram destinadas à professora-regente da turma, o que desencadeou um deslocamento de uma situação bastante recorrente no ambiente escolar, que é a produção de textos para a escola.

Os memes produzidos possibilitaram uma motivação para a interação entre os pares, pois envolveram situações que tinham sido compartilhadas pelos colegas. Essa característica é comprovada em Santos, Colacique e Carvalho (2013), que consideram que os memes são "formas de narrativas do cotidiano que, por meio do humor, permitem aos internautas ressignificarem e reinterpretarem os ambientes e acontecimentos que os cercam." (p. 154), pois ao conceber imageticamente aspectos da realidade, trazem em seu viés cômico elementos para que a imaginação recrie/reinterprete a realidade por ele representada" (p. 138).

A produção de sentidos para os memes exigiu a mobilização de conhecimentos anteriormente vivenciados, evidenciando que a interação é, por excelência, o campo da intersubjetividade, porque se constitui, na maioria das 


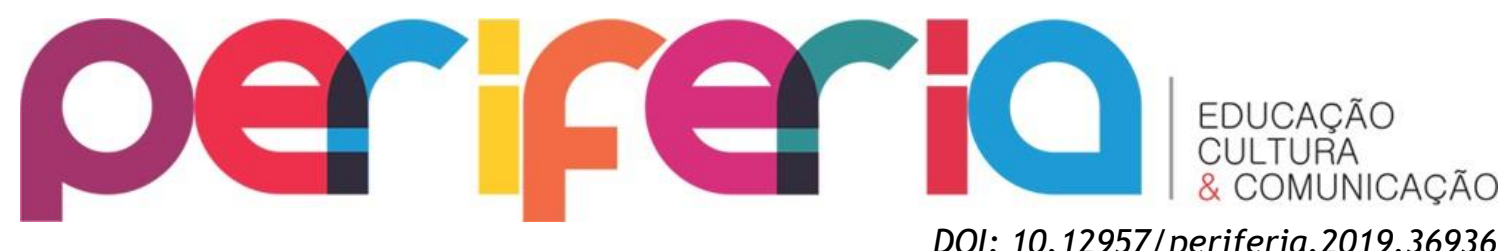

vezes, como base na atenção ao jogo de sentidos estabelecido pelos partícipes da situação comunicativa.

Constatamos também a presença como símbolos, palavras e expressões, que são típicas dos memes que circulam na contemporaneidade em redes sociais, como @, 10/10, friendzone. Todos os textos foram postados em rede social e circularam em ambiente digital, com um tom informal e com viés humorístico.

Além disso, observamos a presença de várias semioses (cores, palavras, imagens estáticas ou em movimento). Essas semioses contribuíram para o processo de produção de sentidos e veicularam informações que foram compartilhados entre usuários do aplicativo de whatsapp - por meio de projetos de dizer de cada enunciação envolvida. Os memes foram constituídos de imagens que já se encontram disponíveis na internet, como é o caso da imagem do jogador da Bélgica.

Para a produção, o aluno utilizou de uma imagem em movimento como uma metáfora para uma situação embaraçosa vivenciada na vida escolar, qual seja, o fato de ficar em recuperação escolar, conforme se verifica no link: https://www.youtube.com/watch?v=txpyeFedrJl\&feature=youtu.be. A partir desse exemplo, podemos constatar que a constituição dos discursos se efetivou como uma resposta à proposta feita pela professora. No entanto, os textos não se direcionaram especificamente a ela, mas a outros interlocutores, dadas às especificidades do gênero meme.

Outra produção que destacamos é a que se encontra disponível no seguinte link:

https://www.youtube.com/watch?v=0_7palfsAsY\&feature=youtu.be. motivação para a produção desse texto foi o equívoco cometido pela colega durante a gravação de um vídeo para uma apresentação em outra disciplina. 0 erro tornou-se um meme, com a incorporação de outra cena (https://m.youtube.com/watch?v=v_unAXI2OfE), retirada do filme "Corra que a Polícia vem aí". Nesse sentido, podemos evidenciar a presença de um processo intertextual, mas que possui dimensões dialógicas, uma vez que os sentidos são produzidos a partir da interação dos interlocutores em uma 


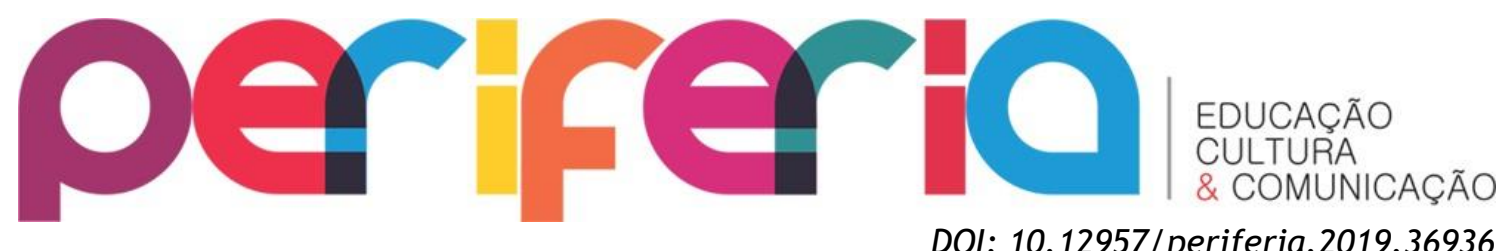

enunciação. Assim, o vídeo assistido por outros espectadores sem 0 conhecimento do contexto que lhe deu origem terá um sentido diferente daquele que os alunos da turma produziram.

No que tange ao processo de textualização, os memes produzidos proporcionaram a discussão de vários elementos. No meme supracitado, os alunos exploraram o recurso da repetição com a finalidade de dar ênfase ao equívoco cometido pela aluna, além de gestos, cenários, cores, imagens em movimento, sons, gestos, expressões faciais, palavras etc. Essas escolhas representam a dinamicidade da língua, que não se limita à reprodução de padrões e convenções regularizados, uma vez cada ato de linguagem depende da seleção de recursos semióticos específicos que servem aos propósitos dos participantes do momento de enunciação (COPE; KALANTZIS, 2008, p. 204).

Para finalizar nossa análise, destacamos a reflexão acerca do compromisso ético nas redes sociais. Antes da produção, os alunos discutiram a responsabilidade ética de cada cidadão ao compartilhar memes. Nesse sentido, um dos memes produzidos destacou a dimensão ética do processo de circulação desse tipo de texto, uma vez que pode disseminar preconceitos. Nessa direção, Castro (2017, p. 6) considera que o gênero meme é, na maioria das vezes, “recorrente em meios virtuais, sob uma representação multimodal, encapsulando informações e/ou porções de textos, na medida em que assumem algumas funções de indicação de críticas e de posicionamentos ideológicos ou, ainda, criação de efeitos de humor."

Considerando essa perspectiva, podemos nos remeter à produção textual disponível no link: https://www.youtube.com/watch?v=J1HGIXOkdW0\&feature=youtu.be, que retextualiza um tipo de meme que circula recorrentemente nas redes sociais, em que são tomadas pessoas que sempre são submetidas às situações de preconceito (negros, homossexuais, deficientes etc). Essa produção evidencia que os memes podem cumprir a finalidade de evidenciar ideologias sociais incorporadas pelos grupos de interação.

Segundo Passos (2012, p. 10), é relevante que se “promova uma reflexão sobre a imagem, a construção linguística, o conhecimento prévio, entre outros 


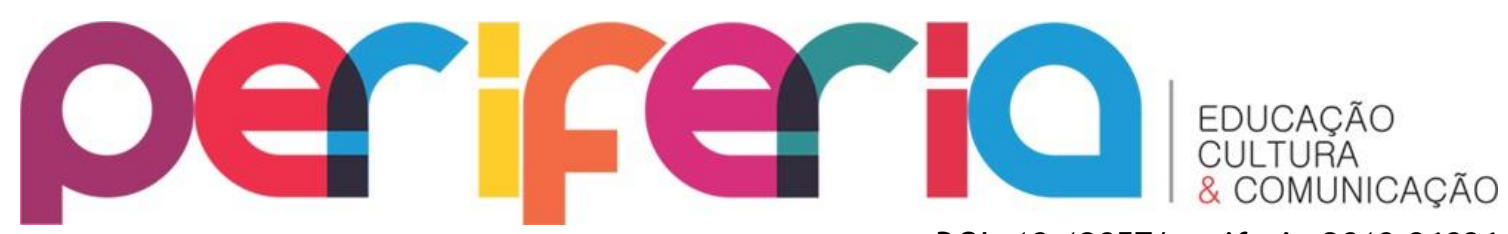

DOI: $10.12957 /$ periferia.2019.36936

aspectos que são relevantes ao conhecimento do aluno e sua consciência crítica sobre o uso de linguagens". Para tal, segundo Pennycook (2001), o despertar crítico envolve uma postura transgressora, capaz de questionar as regras que organizam a sociedade, na busca por transformar a realidade e exercer efetivamente a cidadania. Assim, é relevante ressignificar o nosso modo de estar no mundo, com vistas a torná-lo mais igualitário e mais inclusivo.

\section{CONSIDERAÇÕES FINAIS}

Este artigo teve por intenção provocar uma reflexão sobre o trabalho com o gênero meme em sala de aula. Para tal, buscamos contextualizar o surgimento desse gênero e seus redimensionamentos a partir da disseminação das TDIC. Para enriquecer a pesquisa apresentada, optamos por analisar memes produzidos por alunos do ensino médio, buscando empreender uma discussão em uma perspectiva discursiva.

Diante do exposto, podemos considerar que o gênero meme apresenta potencialidades para o encaminhamento de metodologias de ensino que contribuem para a ampliação de habilidades relacionadas aos multiletramentos, uma vez que permitem uma análise das condições de produção dos textos que circulam em ambientes digitais, espaços tão caros para interação entre adolescentes. Nesse sentido, podemos considerar que o trabalho com os memes propicia um redimensionamento das práticas de leitura e de produção de textos na escola, uma vez que possibilita uma articulação com o cotidiano social, a exploração de diferentes semioses e suas possibilidades indiciadoras de sentido e ordenamentos sobre a questão ética, essencial às práticas de compartilhamento de mensagens.

Assim, a partir do trabalho empreendido, é relevante considerar que os memes, apesar de sua natureza notadamente informal, podem instaurar momentos formativos, capazes de mobilizar os alunos para a produção efetivamente autoral de textos. Além disso, podem estimular a criatividade, aumentar o interesse pela reflexão sobre os usos da linguagem, enfim, ampliar habilidades relacionadas aos multiletramentos, uma vez que incitam o 


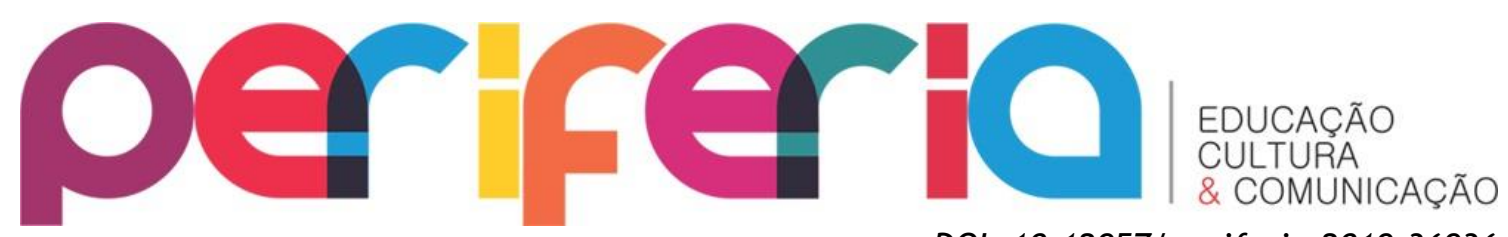

DOI: $10.12957 /$ periferia.2019.36936 manuseio operacional das tecnologias e um olhar crítico sobre os processos de produção, circulação e recepção de textos que integram o cotidiano social.

\section{REFERÊNCIAS}

BAKHTIN, M.M. Estética da Criação Verbal. Trad. do russo por Paulo Bezerra. 6. ed. São Paulo: WMF Martins Fontes, 2011.

BAKHTIN, M. Teoria do Romance I. A Estilística. Trad. do russo por Paulo Bezerra. São Paulo: Editora 34, 2015.

CASTRO, L. G. F. O meme digital: construção de objetos de discurso em textos multimodais. 2017. 79 f. (Dissertação), Mestrado em Letras, Curso de Programa de Pós-graduação em Letras, Universidade Federal de Sergipe, Sergipe, $2017 . \quad$ Disponível em: <https://ri.ufs.br/bitstream/riufs/8197/2/LORENA_GOMES_FREITAS_CASTRO. pdf>. Acesso em: 01 jul. 2018.

COPE, B.; KALANTZIS, M. Language education and multiliteracies. In: HORNBERGER, N. H. (Org.). Encyclopedia of language and education, v.1. New York: Springer, 2008. p. 195-211.

COURTINE, Jean-Jacques \& MARANDIN, Jean-Marie. "Quel objet pour l'analyse du discourse?". In: CONEIN, B.; COURTINE, J. J.; GADET, F.; MARADIN, J. J.; PÊCHEUX, M. Matérialités Discursives. Lille: Presses universitaires de Lille, 1981, p. 21-33.

DAWKINS, Richard. O gene egoísta. Belo Horizonte: Editora Itatiaia/ São Paulo: Universidade de São Paulo, 1979.

ESCALANTE, P. R. P. O potencial comunicativo dos memes: formas de letramento na rede digital, 2015. (Dissertação), Mestrado em Comunicação Social, Universidade do Estado do Rio de Janeiro. Faculdade de Comunicação Social. Disponível em: < http://www.ppgcom.uerj.br/wpcontent/uploads/Disserta\%C3\%A7\%C3\%A3o-Pollyana-Escalante.pdf>. Acesso em 10 de maio 2018.

FERREIRA, H.; VILLARTA-NEDER, M. A. Textualização e Enunciação em texto multimodal: análise do vídeo de animação Escolhas da Vida. Revista Prolíngua. v. 12, n. 2- out/dez de 2017. Disponível em: < http://www.periodicos.ufpb.br/ojs/index.php/prolingua/article/view/38233 >. Acesso 10 jan. 2018.

GERALDI, J.W. A Aula como acontecimento. São Paulo: Pedro \& João Editores, 2015. 


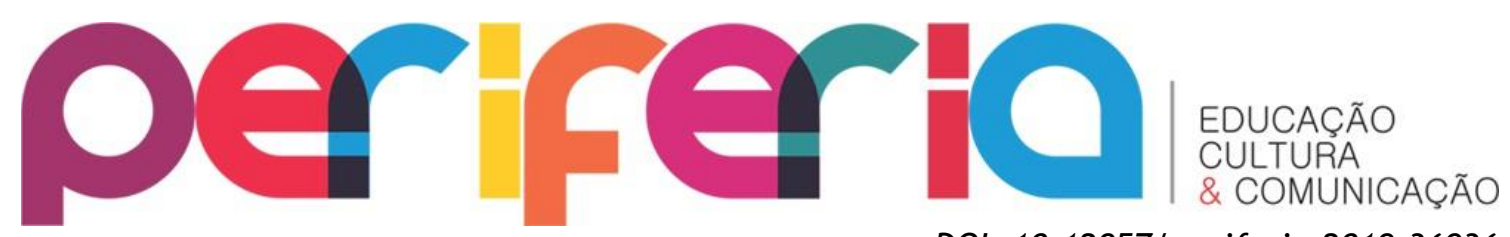

DOI: $10.12957 /$ periferia.2019.36936

GUERREIRO, A.; SOARES, N. M. M.. Os memes vão além do humor: uma leitura multimodal para a construção de sentidos. Texto Digital, Santa Catarina, v. 12, n. 2, p.185-205, 20 dez. 2016. Universidade Federal de Santa Catarina (UFSC). Disponível em: <https://periodicos.ufsc.br/index.php/textodigital/article/viewFile/18079288.2016v12n2p185/33189>. Acesso em: 10 jun. 2018.

HORTA, N. B. O meme como linguagem da Internet: uma perspectiva semiótica. 2015. Dissertação (Mestrado em Comunicação) - Universidade de Brasília, Brasília, 2015.

JUNQUEIRA, A. H. Os memes e sua apropriação pelo marketing digital: a experiência da rede brasileira de fastfood Giraffas. Signos do Consumo, São Paulo, v. 8, n. 2, p. 19-30, jul./dez. 2016.

KRESS, G.; VAN LEEUWEN, T. 2006. Reading images: the grammar of visual design. $5^{\text {th }}$. London and New York: Routledge.

MARTINO, L. M. S.; GROHMANN, R. A longa duração dos memes no ambiente digital: um estudo a partir de quatro geradores de imagens online. Revista Fronteiras - estudos midiáticos, v. 19, n. 1, p. 94 a 101, jan./abr. 2017.

MEILI, A. M.. Os memes no YouTube: uma aplicação da intertextualidade como categoria analítica. C\&S: Comunicação \& Sociedade, São Bernardo do Campo, v. 35, n. 2, p.353-381, jun. 2014. Disponível em: <https://www.metodista.br/revistas/revistas-

metodista/index.php/CSO/article/viewFile/3325/4215>. Acesso em: 14 jan/jun. 2018.

PASSOS, M.V.F. O gênero "meme" em propostas de produção de textos: implicações discursivas e multimodais. Anais do SIELP. v. 2, n. 1. Uberlândia: EDUFU, 2012. Disponível em: <http://www.ileel.ufu.br/anaisdosielp/wpcontent/uploads/2014/07/volume_2_artigo_204.pdf>. Acesso em: $12 \mathrm{dez}$. 2017.

PENNYCOOK, A. Critical applied linguistics: a critical introduction. Mahwah, NJ. Laurence Associates, 2001.

RAMOS, A. V.; MELLO, A.; CAVALCANTTI, C. L. C. Semiosfera: Exploração conceitual nos estudos semióticos da cultura. In: MACHADO, I. (Org). Semiótica da Cultura e Semiosfera. São Paulo: Annablume/Fapesp, 2007.

RECUERO, R. Redes sociais na internet. Porto Alegre: Sulina, 2009.

RECUERO, R. Memes em weblogs: proposta de uma taxonomia - conexões nas redes midiáticas. Revista Famecos, Porto Alegre, n. 32, p. 23-31, abr. 2007. Disponível em: 


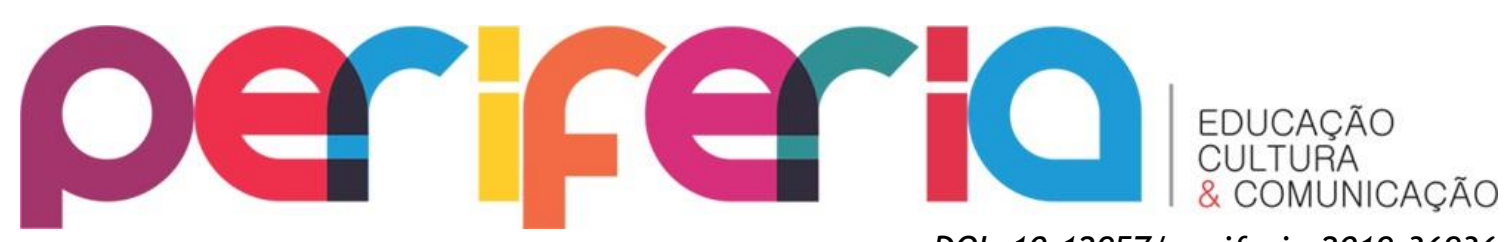

DOI: $10.12957 /$ periferia.2019.36936

http://revistaseletronicas.pucrs.br/ojs/index.php/revistafamecos/article/vie w/3411 >. Acesso em: 10 jun. 2018.

RIBEIRO, A. E. Textos multimodais: leitura e produção. São Paulo: Parábola Editorial, 2016.

ROJO, R.H. Protótipos didáticos para os multiletramentos. In: ROJO, R. H. R; MOURA. E. Multiletramentos na escola. 2. ed. São Paulo: Parábola Editorial, 2016.

ROJO, R.H. Pedagogia dos multiletramentos. In: ROJO, R. H. R; MOURA. E. Multiletramentos na escola. 2. ed. São Paulo: Parábola Editorial, 2016.

SHIFMAN, L.. Memes in digital culture. Cambridge: MIT Press, 2014.

SANTOS, E.; COLACIQUE, R.; CARVALHO, F. da S. P. de. A autoria visual na internet: o que dizem os memes? Quaestio, Sorocaba, SP, v. 18, n. 1, p. 135 157, maio 2016. Disponível em:

<http://periodicos.uniso.br/ojs/index.php/quaestio/article/view/2570/2168> . Acesso em 10 jun. 2018.

SANTOS, E. O. dos; SANTOS, R. dos. A tessitura do conhecimento via mídias e redes sociais da internet: notas de uma pesquisa-formação multirreferencial em um curso de especialização. Educ. foco, Juiz de Fora, v. 18, n. 1, p. 4369, mar. / jun. 2013. Disponível em: < http://www.ufjf.br/revistaedufoco/files/2014/06/texto-2.pdf>. Acesso em 5 jun. 2018.

SILVA, A. A. Memes virtuais: gênero do discurso, dialogismo, polifonia e heterogeneidade enunciativa. Revista Travessias, v. 10, n. 3, p. 341 a 361 , set./dez., 2016.

SILVA, M. P. B.; FRANCELINO, P. F.; MELO, R. M. Relações dialógicas em memes da campanha publicitária "Eu sou a Universal”. Revista Prolíngua. v. 12, n. 2, p. 175 - 187, out/dez de $2017 . \quad$ Disponível em: <www.periodicos.ufpb.br/ojs/index.php/prolingua/article/download/38241/1 9384>. Acesso em 05 jun. 2018.

SOUSA, C. As relações dialógicas na produção de 'memes' na internet. Littera Online, Maranhão, v. 1, n. 10, p.1-15, 2015. Disponível em:< http://www.periodicoseletronicos.ufma.br/index.php/littera/article/viewFil e/3561/1597>. Acesso 15 jul. 2018.

TAKAKI, N.H. Letramentos na sociedade digital: navegar é e não é preciso. Jundiaí: Paco Editorial, 2012.

VIEIRA, E. A. P.; SILVA, F. D. S.; ALENCAR, M. C. M. A canção roda-vida: da leitura às leituras. In: ROJO, R. H. R; MOURA. E. Multiletramentos na escola. 2. ed. São Paulo: Parábola Editorial, 2016. 


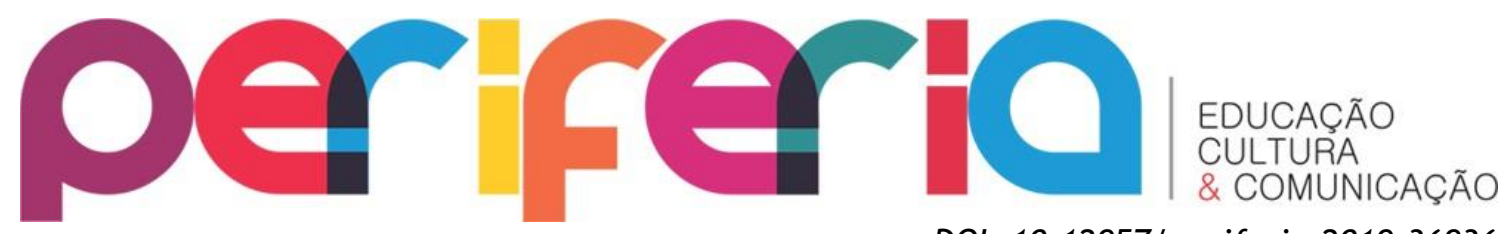

DOI: 10.12957/periferia.2019.36936

VOLÓCHINOV, V.N. Marxismo e Filosofia da Linguagem. Problemas fundamentais do método sociológico na ciência da linguagem. Trad. do russo por Sheila Grillo e Ekaterina Vólkova Américo. São Paulo: Editora 34, 2017.

ZABALZA, M.A. Diários de aula: um instrumento de pesquisa e desenvolvimento profissional. Porto Alegre: Artmed, 2004. 